\title{
Some Unrecorded Incidents of the Jacobite Risings (Continued)
}

\section{Author(s): Alexander Carmichael}

Source: The Celtic Review, Vol. 6, No. 24 (Apr., 1910), pp. 334-348

Stable URL: http://www.jstor.org/stable/30070229

Accessed: 27-06-2016 05:09 UTC

Your use of the JSTOR archive indicates your acceptance of the Terms \& Conditions of Use, available at

http://about.jstor.org/terms

JSTOR is a not-for-profit service that helps scholars, researchers, and students discover, use, and build upon a wide range of content in a trusted digital archive. We use information technology and tools to increase productivity and facilitate new forms of scholarship. For more information about JSTOR, please contact support@jstor.org. 
but far beyond its borders, among the Teutonic tribes who gave their name to England. They, among the Celts, as the Normans among the Teutons, had the highest ideal of organisation and of law, as well as the foremost military qualities, and with them, more easily and completely than with any other race, the Norman blood blended to form the guiding element of a strong, a logical, and an enduring national character. The perfervidum ingenium Scotorum in intellectual pursuits, the proud valour which inspired the French proverb, fier comme un Ecossais, are in no small degree due to the special Scottish strain in the blood of modern Scotsmen, and discarding all fabulous and mythical antiquity, we may yet affirm that no race has more cause to be proud of its far descended royal line, or has produced a representative whom it has more reason to revere than he of whom it was written, "There was not born of the Gaidhel a being more illustrious, or more wise, or of better family than Colum Cille. There came not of them any person who was more modest, more humble, or more lowly.'

\section{SOME UNRECORDED INCIDENTS OF THE JACOBITE RISINGS}

Alexander Carmichael

(Continued from vol. vi. p. 283)

Prince Charlie

Prince Charlie and his few followers landed in Eriskay from France on the 23rd of July 1745. Eriskay is a hilly, rocky, boggy, sandy, small island standing in the sound between Barra and Uist. There was only one isolated family there then: there are one hundred congested familiese now in Eriskay. The Prince and his followers slept two nights in Eriskay, sailing on the 25th July 1745 for Lochnan-Uamh, lying between Arasaig and Moideart.

Near where the French frigate anchored, a boat from 
Barra lay ready to sail for home, laden with rafters for roofing a house. The boat belonged to John Campbell, crofter, Glen, Barra. The captain of the frigate asked John Campbell if he would help in landing stores. Campbell and his men joined in the work willingly, the rafters being thrown ashore. The stores were thrown into pits near the head of the loch, brushwood being strewn over the closed trenches.

When the work was done the French captain asked John Campbell what he charged for his effective help. Campbell said that he did not want money, but that if he had meal to spare he would be glad, meal being scarce in Barra that summer.

The Barra skiff was laden with bags of flour and barrels of biscuits, with casks of wine and boxes of brandy. There was much joy and rejoicing, much sharing of goods and many mutual good wishes in Barra that year !

When the French frigate arrived the men of Barra had a pot of strubain (cockles) upon the fire for their dinner before sailing for home. Pot and cockles were overlooked in the joyous mood of the Barra men; and pot and cockles stood unmolested upon the tripod of stones long years afterwards.

The scene is changed. After Culloden Prince Charlie wandered a fugitive through the Western Highlands and Western Isles. He slept for several weeks in a cave in South Uist. Before then the cave was called 'Uamh Chrothadail,' cave of Corrodal ; since then the cave is known as 'Uamh a Phrionnsa,' cave of the Prince. The cave is in the face of a small cliff on the side of a steep, narrow dell running down to the sea a few yards below. It lies lengthwise in the face of the rock a few feet long, a few feet wide, a few feet high and with a sloping floor.

Chambers says that a hundred persons knew the hidingplace of the Prince. A Gaelic proverb says :-

'Cha sgeul ruin e bho chuala triùir e.'

'It is no secret since three have heard it.' 
It would be safe to say that several thousand persons knew that the Prince was in Corrodal. Practically the people of Barra, South Uist, Benbecula, North Uist, Harris, Lewis, Skye, and the Small Isles, knew that the Prince was in South Uist.

He wandered among the hills and moors, among the crofters, of which the place was then full, although there are none now. His neighbours far and near vied with one another in supplying his needs with the best they had in their power, and often at the risk of their lives from the soldiery who were scouring the country.

There was a reward of thirty thousand pounds upon the head of the Prince dead or alive, probably equal to a hundred thousand pounds of the present currency.

With his usual prejudice and dogmatism Lord Macaulay alleges that the Highlanders did not know the value of money since they did not betray the Prince. The allegation is as unjust as it is ungenerous. No one believed the allegation, nor did Lord Macaulay. ${ }^{1}$

Mr. John Macaulay, grandfather of Lord Macaulay, was minister of South Uist at the time. The church was then at Killpheadair, and the minister lived near the church, and within a few miles of the hills where the Prince wandered. The situation of the church is indicated in the lines of the Eigg poet :-

\author{
'Is iomadh maighdean sparasach \\ Dha math dha'n tig an earasaid \\ Eadar Baile-mhanaich 's Caolas Bharraidh \\ An deigh ort. \\ Tha tighinn fotham! fotham! fotham! \\ Tha tighinn fotham fotham! fotham! \\ Tha tighinn fotham! fotham! fotham! \\ Tha tighinn fotham eirigh.
}

\footnotetext{
1 Lord Macaulay is not always consistent. In another place he says : 'A gentleman of Skye or Lochaber, whose house was no better than a pigstye, could yet conduct himself with all the graces of Versailles.' Again, 'It would be a shame that a Highland boy with no more book education than an English boor should be compared intellectually with an English boy of the same class.' And again, 'If the love which the Highlander had for his native chief could be transferred to his lawful sovereign what a gain that would be for England !'
} 
Tha cuid 's an Fhraing 's an Eadailt diu

Tha cuid an Eilean Bheagrum diu

'S nar bheil latha teagaisg nach bi

Treud an Cillpheadair diu.

Tha tighinn fotham ! fotham! fotham !

Tha tighinn fotham! fotham! fotham!

Tha tighinn fotham! fotham! fotham!

Tha tighinn fotham eirigh.'

'There's many a haughty maiden

To whom becomes the 'earasaid'

From Monkstown to Barra Sound

Deeply bound in love of thee.

Methinks! methinks! methinks!

Methinks! methinks! methinks!

Methinks! methinks! methinks!

Methinks to rise and wield the claymore.

There are some in France and Italy

There are some in Isle of Beagrum

Nor is there a preaching day

But is in Killpheadair a troop of them.

Methinks! methinks! methinks !

Methinks! methinks! methinks!

Methinks! methinks! methinks!

Methinks to rise and wield the claymore.'

When Mr. John Macaulay heard that the Prince had left Corrodal for Stornoway he sent a messenger to his father, Mr. Aulay Macaulay, minister of Harris. Mr. Aulay Macaulay and his five sons were strong anti-Jacobites and as strong pro-Williamites. He heard that the Prince was in Scalpay, a low-lying, rocky, mossy island upon the east side of Harris. He and some relatives of his own and of his wife hurried away at midnight to secure the Prince. The Prince was living in the house of Mr. Donald Campbell, tacksman of Scalpay, a descendant of the House of Argyll. Mr. Donald Campbell was exceptionally big and powerful, and the greatest swordsman in the Isles, whether, as the narrator said-le claidheamh cul no le claidheamh cruachain

VOL. VI. 
-with back sword or hip sword-le claidheamh mor no le claidheamh beag-with big sword or small swordle claidheamh da-laimh no le claidheamh leth-laimhwith two-handed sword or with one-handed sword-le claidheamh cul no le claidheamh leis-with back sword or thigh sword. He was generous and hospitable, and patient too, till roused, but when roused like Naois :-

'B 'i choimeas an fhairge gharg.'

'His likeness was the wild ocean.'

'Ann an glasadh graidh na camhanaich'-in the beloved grey dawn of the morning, a messenger came in to tell Donald Campbell that a boat from Mobhag a Chuain-Movaig of the Ocean-was making for Scalpay. Donald Campbell hurried down to meet the boat with his claymore in his hand. This was the minister of Harris, Mr. Aulay Macaulay, and some relatives.

'What is the reason for this rare visit to this forgotten island, Mr. Aulay ?' said Donald Campbell. 'We have heard that you have got the Prince in Scalpay, and we have come to seize him.' 'Yes, the Prince is in my house, but before a hair of his head is hurt it will be over my prostrate body. I am as much against the Stuarts as you are, Mr. Aulay, and I would fight them in the field, but the Prince is foodless, homeless, and friendless, and alone in my house, and the first man among you who comes ashore to seize him I will cleave to the ground. I care not lay or cleric, courtier or cloisterer.' And with that Donald Campbell handled his huge sword and fingered its keen blade as if to make sure that all was right.

All in the boat knew that Donald Campbell's temper was wild when roused, that his arm was strong when raised, and that his sword was powerful when unsheathed, and they discreetly refrained from landing.

On returning from his fruitless visit to Stornoway, the Prince called to see his benefactor Donald Campbell. He found, however, that Donald Campbell had had to flee to 
the mountains of Harris, where he had to remain in exposure for five months because of the shelter he had given the Prince for five nights.

\section{Sanais a Phrionnsa}

The 'arm dearg,' red army, were in search of Prince Charlie, but were never able to seize him. As the 'dearganaich,' red ones, searched for the Prince the people watched for the 'dearganaich' and warned the Prince.

The Prince was once in a glen in Kintail [the reciter could not remember the name].

The 'dearganaich' had a piper, and the piper made the words and composed the air and played the warning as they neared the resting-place of the Prince. And the piper played so well that the Prince understood the warning and escaped. When the 'dearganaich' came up they found the ' cos,' cleft, still warm but the Prince away. They were angry and seized the piper, and cut off the first joints of his two thumbs.

'Tha'n fhoill air do chulaibh

Mar a duisg thu, fhir ruaidh

Tha'n fhoill air do chulaibh

Mar a duisg thu gu luath.

Mar a duisg! mar a duisg!

Mar a duisg thu fhir ruaidh!

Mar a duisg ! mar a duisg!

Mar a duisg thu gu luath!

T'aghaidh ris an aonaich

A ghaolaich fhir ruaidh !

T'aghaidh ris an aonaich

A ghaolaich gu luath!

An t-aonach! an t-aonach!

A ghaolaich fhir ruaidh !

An t-aonach! an t-aonach !

A ghaolaich gu luath !' 
'Danger is behind thee

If thou wake not, red man!

Danger is behind thee

If thou wake not, and soon.

If thou wake not! if thou wake not!

If thou wake not, red man !

If thou wake not! if thou wake not!

If thou wake not, and soon.

Thy face to the hills, Thou beloved red man!

Thy face to the hills,

Thou beloved one, and soon.

To the hills! to the hills!

Thou beloved red man!

To the hills! to the hills !

Beloved one, and soon.'

\section{Donald Livingstone}

Donald Livingstone, Bun-a-mhuilinn, Morvern, was of the Livingstones of Achnacree, Benderloch. These Livingstones of Achnacree had been the keepers of the Royal Forest of Dail-an-eas till this was wrested from them by the Macdonalds of Glencoe.

The Livingstones of Achnacree were of the same line as the Livingstones of Bachuill, Lismore, keepers of the Staff of Saint Moluag. The two families separated many centuries ago, yet they still resemble one another, physically, mentally, and characteristically. Dr. David Livingstone was of the Lismore Livingstones and resembled that family so closely that the late Baron Alexander Livingstone, Bachuill, was taken for him several times, to the great confusion of the singularly shy, modest Baron. Similarly the late Robert Livingstone of the Achnacree Livingstones had been mistaken for the famous missionary, and that by men and women who had seen and spoken to the great traveller. Honest Robert Livingstone said that he had never been so much put out as when a stout, elderly lady 
tourist on Oban pier insisted upon kissing his hand ' once more after his great travels.' Bystanders who knew the facts were bursting out in laughter at Robert Livingstone's speechless confusion!

So much for the tenacity of family characteristics.

Donald Livingstone of Bun-a-mhuilinn was eighteen years of age in the year of Culloden. He was very stout, strong, active, and hairy, and he was known as Domhull Mollach-Hairy Donald. There was kinship and fostership between the Lismore and Benderloch Livingstones and the Stuarts of Appin. Donald Livingstone from Morvern joined his friends the Stewarts of Appin and fought with them at Culloden, as did also his clansman Donald Livingstone from Lismore.

The sibyl of the place predicted that nine Donalds would fall carrying the blue banner of the Stewarts. The Carmichaels were the standard-bearers of the Stewarts, and the first Donald to fall was Donald Carmichael, and seven other Donalds fell in succession.

When the eighth Donald fell Donald Livingstone took up the banner, and tearing it from the staff, wrapped the banner round his body. He had hardly done this when a musket ball struck him on the breast and knocked him down. The folds of the silk broke the force of the bullet, thereby saving the life of Donald Livingstone, although the impact knocked him down and rendered him senseless. Donald would never show the bullet mark to any one, nor was the bullet mark even seen by any one till he died. He never knew how long he lay breathless and speechless upon the ground, but when he opened his eyes he saw a riderless steed rushing down in his direction, trampling upon the dead and the dying in its wild career.

When the steed was nearly upon him, Donald Livingstone exerted all his strength and seizing the bridle sprang into the empty saddle of the frightened horse, and was out of the luckless field with all possible haste.

Two English troopers saw Donald Livingstone riding 
away from the field, and they followed him. When he saw that his exhausted horse was unable to save him from his pursuers he wheeled round and faced them. The nearest trooper aimed a blow at his head. Donald Livingstone, already a good swordsman, parried the blow, and coming down upon the head of his opponent clove him to the chin. The second trooper was about to join in, but when he saw the fate of his companion he wheeled about and fled.

Donald Livingstone did not know what to do with this second troop horse now upon his hand, whether to leave it or to take it. He thought, however, that he might see some needful fugitive like himself, so he led the horse and renewed his journey. Upon going round the first knoll on his way he heard the call of a familiar voice from a cleft in some scarred rocks behind him. He turned, and this was a neighbour badly wounded and bleeding profusely. Donald stanched the bleeding as best he could and helped his friend to mount the horse and the two rode on.

Upon reaching a secluded corrie they dismounted to rest their tired bodies and their wearied horses. They made di-leum-fetters of withes-and placing these upon their horses, left them to graze while they themselves went up the hill and hid behind big boulders beyond the reach of troopers.

By and by a troop of cavalry rode along the way below them. Hearing the noise of their companions, the two horses in the fetters neighed again and again.

The troopers suddenly stopped and listened and looked around, but could see nothing. The neighing echoed round the corrie among the rocks and the English troopers turned and fled, evidently fearing that they were ambuscaded.

The two youths made their way home, resting by day and riding by night till they reached Morvern. They betook themselves to the hills, resting in caves by day and getting food from friends by night, and shifting from place to place to avoid the 'red coats.' Upon several occasions they would have fallen into the hands of the soldiery had 
it not been for the daring courage and resourcefnl actions of Donald Livingstone.

As the night lengthened and the day shortened, the patience of Donald Livingstone shortened also. He moved about everywhere in search of news of the Prince or news of any kind, but he could get none save of the brutalities of the soldiers and of the woes of the people.

Failing to hear anything of the Prince in Morvern, Donald Livingstone resolved to swim from Morvern to Mull in the hope of getting news. He was a good swimmer and had crossed and recrossed the Sound of Mull many times carrying his clothes behind his neck. Several times he had narrowly escaped being shot in mistake for a seal by passing ships. Upon one occasion a bullet grazed his ear. A second bullet might have ended his career had he not risen up in the sea and shown himself to the astonished people on board the vessel.

In swimming from Morvern to Mull Donald Livingstone came dangerously near a warship passing up through the Sound of Mull. The night was calm and clear, but occasionally cloudy, and before he was aware of her presence the strong tidal current of the Sound carried him towards a ship-of-war moving westward to join the many other warvessels in search of the Prince.

Upon landing in Mull, Donald Livingstone made his way to Drum-fionn in the neighbourhood of Tobermory. From this vantage-ground he saw two ships-of-war towing in two other ships-of-war, bringing news of their own defeat and of the escape of the Prince. These were the two English war-vessels which the French war-vessel defeated and eluded in Loch-nan-Uamh. Much excitement ensued in Tobermory over the news that the Prince had escaped, and it took the daring Donald Livingstone no time to be in the midst of the commotion.

Donald retraced his steps, and recrossed the Sound. This was the most exciting and perilous journey. In mid-channel he encountered a large shoal of herring 
followed by a huge whale, blowing loudly and throwing up volumes of water high in the air. In after life Donald Livingstone confessed that the whale frightened him. He was wondering how he could escape if the whale were to swallow him. Would he be expelled from the stomach of the whale as Jonah had been? This and many other questions passed through his mind while he was near the whale.

Donald Livingstone continued to hide himself as before, gradually coming more and more into the open as the soldiers were gradually withdrawn.

The banner of the Stewarts had been safely concealed, no one knowing where it was except Donald's own family.

Before long this daring youth set out for Appin, carrying the precious banner next his skin round his body, and riding the horse of the slain trooper. He gave the flag into the hands of the chief of the Stewarts of Appin, now bowed down with age and sorrow. $\mathrm{He}$ then went and gave the English troop horse to James Stewart, better known as Seumas a Ghlinne-James of the Glen. This was in acknowledgment of a kindness shown by James Stewart to Donald Livingstone's father in sending him the year before a bag of barley for seed corn. ${ }^{1}$

Things had hardly settled down, and the soldiery had hardly been withdrawn, when Donald Livingstone began to cater for the garrisons of Fort William and of Fort Augustus. He bought cattle from the people and sold them to the

1 It was this James Stewart who was executed for the murder of Colin Campbell, Glenuir. It is a known fact, however, that it was not James Stewart but another Stewart who fired the fatal shot. A secret compact was made among six leading Stewart men to kill Colin Campbell, factor upon the forfeited estates, for his evictions and cruelties towards the tenants. Lots were drawn, and the lot fell upon a certain Stewart gentleman. James Stewart was suspected, tried, and executed. The real culprit pressed to be allowed to declare the guilty and to free the innocent. James Stewart, however, would not listen to this, declaring that he was in the faction and that he might as well suffer the penalty as any other one of the party. The writer has this from a high-placed relative of the Stewarts concerned.

The trial of James Stewart was one of the most famous criminal trials of the time. Stevenson, who lived in Appin for a time, deals with it in Kidnapped. 
garrisons and continued this trade during many years. He became a favourite with the officers and men of the garrisons from his daring courage and absolute honesty, and although they knew his history they never molested him.

Notwithstanding his many narrow escapes by sea and land, Donald Livingstone lived to be an old man, dying peaceably in bed at the age of eighty-eight. He never had an illness and never wore trousers-always the kilt. His makeshifts in evading the law against the kilt and the tartan were innumerable. How he escaped was a miracle to all, and could only be accounted for by his dauntless courage and honest nature, which rendered him a favourite with officers and men of the garrisons.

Dr. Macleod, Morvern, remembered Donald Livingstone and many of his daring deeds and his honourable traits. Dr. Macleod said that he used to sit at his door in the coldest weather with a scant tartan kilt over his knees and with a broad blue bonnet over his head, bright and cheerful and happy to the last. He was never inclined to fight his own battles over again, but always ready to tell of the good deeds of other men. Every one had a word of loving admiration for the daring, honest Donald Livingstone, known as Domhull Mollach.

It may be mentioned that the blue banner of the Stewarts of Appin is in the possession of a Stewart of Appin living in Edinburgh. The colour of the beautiful silk is much faded and the cloth is full of bullet holes and bloodstains.

\section{Colonel Macleod of Talisgeir}

Colonel Macleod of Talisgeir was a scion of the Macleods of Dunveagain. In the autumn of 1773 Dr. Johnson, James Boswell and Donald Maclean of Coll visited him at Talisgeir, and were hospitably entertained.

Colonel Macleod had just retired from the Dutch service 
when he was appointed to the command of the militia searching for Prince Charlie through the Western Isles. When it became known that the Prince had left the Isles and was now on the mainland the search in the Isles relaxed and Colonel Macleod was able to come home to see to matters requiring his attention.

Soon after coming home he and some men were 'a doradh '-hand-line fishing -in the open bay of Talisgeir.

They were heaving up the 'cruaidh,' 'cailleach'-stone anchor - of the boat preparatory to leaving for home when a French frigate under full sail bore down upon them. The frigate was thrown up in the wind near the boat, while those on board held out pieces of silver and pointing to the fish in the boat spoke in French. Colonel Macleod replied in French, which pleased and surprised the people of the French ship.

The fish upon the floor of the boat was thrown up on the deck of the ship, and Colonel Macleod and his men were asked on board. Colonel Macleod went on board but he sent his men up to Talisgeir House for milk, cream, and butter, fruit, vegetables, and mutton. Upon the return of the men Colonel Macleod left, but before he left the captain of the frigate said, 'We are in search of Prince Charlie, but know not where to find him nor which way to go.' ' $I$, too, am in search of Prince Charlie, but from a different motive. But,' said Colonel Macleod, placing his finger on Loch-nan-Uamh on the chart before him, 'if you go you may hear of something to your liking. That is outwith my command, and more I must not say.'

The French frigate set all sail and made for Loch-nanUamh, going up to the head of the loch. Here she remained some days to enable the Prince and his followers to come on board. One hundred and thirty men joined the Prince.

Two English men-of-war followed the French man-ofwar into Loch-nan-Uamh, watching all that occurred the while. Two other English ships of war remained in the open sea beyond. The Prince and all with him were de- 
termined to die rather than be captured, and every man on board was prepared to fight to the death.

When the French vessel sailed out of Loch-nan-Uamh on Sunday the 20th September 1746 the first English ship fired at her, doing no damage, however. The French frigate returned the fire of the English ship, breaking her mainmast, bringing down mast-yards and rigging, and injuring many men. When the French ship came opposite, the second English frigate fired, doing no harm beyond a shot through the mainsail. The French ship returned the fire, smashing the rudder and rendering the second English vessel as unmanageable as the first. The two English ships in the open sea contented themselves with firing at long range. The French frigate sailed out and was lost to sight beyond Barra.

The place of embarkation and both sides of Loch-nanUamh were crowded with people, many from long distances come to see the last of the Prince and the last of those who were nearest and dearest to them in the world. Wailing and sorrowing ran through the crowds who surmounted every knoll and hill and vantage-ground along the sides of Loch-nan-Uamh-the weeping and sobbing, relieved now and again by cheer upon cheer when the friendly French ship-of-war, carrying away its precious freight for ever, made good its escape and injured its opponents. The people lingered about, some for several days, unable to leave the scene of so many broken hearts, of so many broken hopes.

All this and much more was told the writer by the late Robert Livingstone, the grandson of Donald Livingstone, who rescued the Stewart banner at Culloden.

Robert Livingstone said that when a boy he had seen an old man from Moideart in his father's house at Bun-amhuilinn, in Morvern, who had been present on the occasion. The old man said that the scene was affecting and indescribable, the grief and the joy, the tears and the smiles, the sorrow and the gladness, the distress and the delight 
alternately swaying the people from hill to hill, from summit to summit along the loch like successive clouds over the sun.

The old man from Moideart remained several days in the house of the father of Robert Livingstone. He was full of stories of the Prince and of his followers, and of the scenes that he himself had witnessed in the long ago of his boyhood.

Robert Livingstone remembered many of the old man's descriptive narratives and rehearsed them with ease and accuracy.

In corroboration of the cannon firing of these ships-ofwar it may be mentioned that cannon balls have been found in the near neighbourhood of Loch-nan-Uamh, and in such positions as left no doubt of the balls having been driven into their places by great force.

\section{DERMAID AND GRAINNÉ}

\section{Donald A. Mackenzie}

I

Hearken ! a space . . . . the bard began his lay

In the red peat-glare of a Ceilidh throng

Grown mute, while, like a bounding stag at bay,

The night-wind faltered. . . . . ' 'Tis of Finn's great wrong

I sing, and Dermaid, who the boar did slay,

And Grainnè false-ah! 'tis the woeful song!-

I sing the days when Finn and all his men

Dwelt by Ben Goolban in the Fairy Glen.

When Finn, far-famed for wisdom and great deeds,

A spouse would seek through Erin far and wide,

On Grainne's neck he put the amber beads-

Green-robed she rose before him in her pride.

Her sire was King of Carmag of the Steeds ;

And ne'er to Alban came a lovelier bride.

Great feasts the Fians gave for seven days,

By night the bale-fires on the bens would blaze. 